\title{
Effect of Micro Teaching Applications Practiced by the Preservice Teachers in the Scope of First Turkish Reading and Writing Lesson on Their Verbal Communication Skills
}

\author{
Mesut Bulut \\ Department of Turkish Education, Faculty of Bayburt Education, Bayburt University, Turkey
}

Copyright $\bigcirc 2016$ by authors, all rights reserved. Authors agree that this article remains permanently open access under the terms of the Creative Commons Attribution License 4.0 International License

\begin{abstract}
Main purpose of this study is to receive opinions of the preservice teachers within the context of micro teaching method in the scope of First Turkish Reading and Writing lesson on controlling individuals/prospective teachers' excitement in Turkish lessons, gaining self-confidence, breath control, holding the floor, developing ability of expressing in the context of verbal skill and verbal communication skills such as stress and intonation. In the study special case study is used. In the process of data collecting semi-structured interview forms prepared for students are used. A certain number of data that is gained from interviews has been commented via descriptive analysis. The research is conducted at a university in the East Black Sea region of Turkey by 20 classroom teaching 3. class students. Preservice teachers prepared a set of materials befitting from instructional Technologies and managed micro teaching applications for 14 weeks in the scope of First Turkish Reading and Writing Education lesson. In the first stage of research requirements of micro teaching and applications were explained for the teacher candidates and they grasped a set of stages required for realizing micro teaching applications successfully. Necessary feedbacks were provided by way of watching the realized applications and video images by the candidates together with the instructor. In the end of the research it has been found out that micro teaching applications made significant contribution to learn a number of subjects such as controlling excitement in Turkish lessons, gaining self-confidence, breath control, holding the floor, developing ability of expressing in the context of verbal skill and verbal communication skills such as stress, intonation and diction in accordance to educational programs formed by the constructivist learning approach.
\end{abstract}

Keywords Turkish First Reading and Writing Education, Micro Teaching Method, Preservice Teachers, Verbal Communication Skill

\section{Introduction}

Communication is a collection of activities directing to realization of sentiments, thoughts and wishes insofar as human imagination permits. In a general expression communication can be identified as sharing of sentiments, thoughts and wishes and in this context meeting in a common point process. "Communication is, in a plain and general expression, is sharing of sentiments, thoughts, information, news and skills, in other words it is a process in which a common ground is created in sentiments, thoughts and behaviors" (p51)[1]. The communication skill that is one of the main requirements of human is appeared as an important element that effects the development of human from the past to the present. Especially in information age humans began to consume information rapidly and in the context of consumption communication skill effect the lives of humans directly. The concept of communication provides the process based on the interaction between individuals. It is important in terms of both society and individual.

Communication is a process in which thoughts, information, sentiments and skills are shared and brings about a change in the behaviors. Communication is not only to speak. Communication is an action by which we can decide what we can express and where we can do it and to make decide correctly and to express what we want to tell succinctly and control if we are understood or not understood. It is an interpersonal and social action [2]. Individuals are successful to the extent of they are able to Express their thoughts and sentiments and the thoughts of the opposite side they can understand [3]. By communication humans perceives the external world and change them into the meaningful messages in their inner world and share these meaningful messages with external worlds. It is a dynamic process. The continuity of this process is based on language. The language that is most effective means of the interpersonal communication effects the communication 
process with all dimensions (p.749)[4]. Language that is identified as expression of sentiments, thoughts and wishes is the most important element of the communication. Individuals reflect their sentiments, thoughts and dreams by way of language (p. 562) [5]. Language is magical regulation that we can use it in communication in verbal or written; we acquire it when we born. It is a strong means that totally is belong to human. It is a system using for transmitting what we think (p.13) [6]. Language is a vocal sign system by which humans tell their wishes. We can also tell our thoughts, sentiments and wishes by making some gestures by hands, head and brows. But by far the most transmitting means is language (p. 9) [7]. Interpersonal communication is realized in the frame of two elements: Speech and speechless. The verbal communication skill that is one of two elements can be identified as interaction of a meaningful language unit based on sound and hearing. The verbal communication is a form of communication in which communication is provided by face to face and language is effectively used. The verbal communication is realized together with language. Thus a language use effectively effects directly verbal communication skill. Language that is played an important role in socializing and saturation of cultural values is by far the most communication means in verbal communication. In the globalized world in the information age communication is realized in an easy way but it is difficult in terms of achieving its purpose. As the attention of human in the information age is needed, a struggle has to be made with most stimuli. The verbal communication is the prevalent communication form from the past to the present. The verbal communication that is based on dialogue is the essence of the interaction in the process of educational activities. Ensuring education is realized in a healthy way is directly proportional with the richness of the verbal communication skill.

In the foundation of the communication lays awareness, being conscious of inner and external world in details. An skillful communicator gets know of both his own inner world, in other word, his own thoughts and behaviours as well as he values the behaviours of others in a realistic way. Getting know of himself means to be aware of his own perceiving, interpreting, reflecting of the others. An skillful communicator gets know of both his own inner world, in other word, his own thoughts and behaviours as well as he values the behaviours of others in a realistic way. Getting know of himself means to be aware of his own perceiving, interpreting, reflecting of the others. The person who knows the opposite person means that he knows well the experience of the others. Facial expressions, stating the body, vibrating the sound or intonation give clues for the inner word of the other person. The person who acquired good communication skills instantly see the clues and evaluates them in realistic way (p. 67-68) [8].

The qualities of the persons whose verbal communication skills have been developed can be expressed in the following way: Articulation of the sounds in correct way, not confuse the sounds, completing the sentences in meaningful way, not to use foreign words, not to use unnecessary words, not to constitute illogical sentences, not to make repeating, to use possibility of the sound relating to lowness and highness, breathing deeply, rapidly, regularly, breathing through chest cavity and diaphragm not to speech while breathing, to articulate the words correctly and plainly, to stress the words and sentences correctly and conveniently, to speech with a correct intonation, not to make sopping that spoils the flowing of the speech, to speech according to the convenience of words, gesture, to speech without falling into repeating, not to use slang expressions, and vernaculars or local dialects, not to give unnecessary sounds while talking, not to give unnecessary details, to speech in hearable sounds (p. 25-33)[9]; ( p.56) [1]. The verbal communication skills have importance for every professional groups. They are by far the most imprtant fort the profession of teaching. Because the profession of teaching consists of activities that are directly based on interaction. For this reason, the skill of using language effectively is necessary for effectiveness of the verbal communication. The success of the verbal communication is based on the used words, face to face communication, observation skill, experience, comparasion, giving examples, to make breath controll, to give importance stress and intonation, to adapt the speed of the speech, to get to know the audience, and to behave according to that, to make selfcriticisim. In this point the weakneses of the students must be removed.

Teacher is the most important factor effecting the quality of education. The behaviours with which individuals comply with society in effective and balanced way are acquired with an effective educational service so teachers must be raised effectively (p. 33) [10]. When the elements such as teacher, physical conditions of classrooms, program and many other countable elements are integrated it may be mentioned a teacher as effective. However, the most important of these elements is teacher[11]. In this context micro teaching method becomes important because with which teacher candidates can speak Turkish in correct, effective and beautiful way and it plays an important role in acquiring ability of statement and reasoning, communication skills, self-confidence and persuasive ability, ability of representation before audience, as well as to be able to speech using stress, intonation, stopping, diction, to correct language and expression faults. They are building Stones in raising teacher, educational methods and micro technical method is an effective educational system that is appeared in this context. "Micro teaching technique" is seen in the body of literature. It is used in education sciences with prevalence.

Micro teaching method has been realized firstly in 1960 in the United State of America by a group instructor at Stanford University in order to enhance the quality of teacher rising program. Micro teaching method has the quality to apply the relation between theoretical and practical information. For this reason, it has been very important element in teacher candidates raising [12]. It is a reduced education which is started to be used firstly in 1960's by Dwight W. Allen and 
his friends. It has been developed in order to provide pre experiment and application, to search the effects of the education in controlled conditions and an educational means for the experienced teachers.

Micro teaching is designed systematically for the teacher candidates and gives them possibility of experiment. Micro teaching is a chance to be able to aware of reality of the teacher role in terms of teacher candidates before school experience. It aims at meaningful activities planning made by the teacher candidates and reach awareness of the skills of them to teach. Micro teaching plays a bridge role between the education acquired at the faculty and application (p. 26) [13]. It can be considered as a simulation which is able to strengthen the first step of the teacher candidates to be taken to the profession, removing their Professional faults, increasing their teaching qualities, especially blending their knowledges about formation information with special educational methods. From a different point of view micro teaching method more than giving skills to the teacher candidate by making exercises evaluating themselves and peers they acquire ability of awareness of their faults and they learned in this way. Application of micro teaching technique is started up by giving a subject to the teacher candidates to make a presentation for 15-20 minutes. Generally the classmates of the teacher candidates play a role as students as being student group. The most important problem in this stage is in a real environment a student gives lectures to the peer group who are known as much as him. However, in this point it must be remembered that the point is to practice a technique not to teach the subject. The stages followed in micro teaching technique are preparing a class planning for 10-15 minutes in a certain subject, teaching a lesson, taping by a video camera -if ever- following the class, evaluating the class by both teacher and the follower group, some correction is made according to the suggestions, contribution and critics, teaching the class by preparing again and again making an evaluation [14]. Micro teaching method is a class practice that is limited, artificial and intensified according to the education in the real classroom environment $[15,16,17,18]$. "Micro teaching method enlarges the perspective of the teacher to his profession, his student and pedagogical understanding. Micro teaching that aims at qualified teacher provides both recreation and learning by presenting Professional and real experiences". Micro teaching technique that is approached again in mote functional context since 1980's has been used in the West prevalently. In our country in some universities, especially in some education faculties and technical education faculties have been used.it is considered as to prepare the teacher candidates before getting into the complex classroom environment. However, micro teaching technique in our country is still scarcely practiced (p.138) [19].

\section{Purpose of the Research}

The main purpose of this research is the preservice teachers within the context of micro teaching method in the scope of First Turkish Reading and Writing lesson on controlling individuals/prospective teachers' excitement in Turkish lessons, gaining self-confidence, breath control, holding the floor, developing ability of expressing in the context of verbal skill and verbal communication skills such as stress and intonation.

\section{Method}

This research that is made for getting views of teacher candidates in relation with the effect of micro teaching application effect on their verbal communication skills which is realized by the teacher candidates is qualifying research.

Qualifying researches are a process in which interrogates social life and the problems related with human with which sensitivity to the social context in which research is created and giving the meaning to them [20,21,22].

This research that is made for this research is the preservice teachers within the context of micro teaching method in the scope of First Turkish Reading and Writing lesson on controlling individuals/prospective is directed to describe an existing situation therefore it is a descriptive research. It is preferred case study method of the descriptive researches. The most important reason to choose case study method is that it gives probability to examine the situation in depth in a way that it comprehensive all data collection tools. In this way the subject to be researched can be examined deeply and comprehensively. In this sampling the scales that are considered important for the selection and the sampling that is chosen according to those scales can be representative with all qualities of the research universe [23, 24].

\section{Sampling of the Research}

The research that is made at a university education faculty in the East Black Sea Region of Turkey is conducted by 20 teacher candidates who continue their license education. In the research purposeful sampling is applied. In the quality researches sampling group is picked up as small in order to examine the sampling thoroughly. For this reason, instead of haphazard sampling choosing, purposeful sampling $[25,26$, $27]$ is preferred. Sampling criteria determined are considered important for the choosing and it is considered that the sampling choosing according to these criteria is able to represent all the qualities of the research space [28, 23]. There are 12 female, 8 male teacher candidates of the total 20 teacher candidates in the sampling.

\section{Data Collection Tools}

In the study semi-structured interview technique is used as data collection method. This technique is advantageous in terms of posing questions in special subject deeply and if 
answer is not deficient or clear posing again questions to make the situation more explanatory [29]. Interview is one of the data collection techniques that are used largely in the small scaled education research. It is said that in teaching profession it is the most natural practice is talk with individuals [30]. Interviewing form gives more flexibility to the interviewing process by posing open ended questions and gives more possibility to the interviewers and to take more detailed information [20]. In the study semi-structured interviewing form consisting 8 questions is prepared in order to determine the views of the teacher candidates about micro teaching method. When the questions are preparing in the interviewing the related literature is scanned and questions embracing micro teaching method have been prepared. In the first stage the interviewing form consisting 12 questions has been examined by the 2 expert academicians and 4 questions have been taken from the interview and 2 questions have been revised and the number of questions have been reduced to 8 and gave the questions last form. The prepared interviewing form has been practices with the teacher candidates after applications that lasted 14 weeks. Interviews have been made in generally 2 stages that are as follow:

- Teacher candidates have been informed about the interviews to be made or what purposes.

- Teacher candidates have been asked to tell the questions for which they are not sure and have a doubt to give answers in the form of "I have no any idea."

Despite the teacher candidates educate at Education Faculty they had deficiencies about to use Turkish correctly, effectively as well as they lacked self-deficiency and persuasive ability in the context of using Turkish effectively and correctly, to know the particulars of to use language effectively and the verbal communication. In this subject it talked with the teacher candidates and they have been relieved. Interviews has started up when they felt that they have been ready. The questions in the form of interviewing have been posed to the candidates and according to the answers gave the sub questions also have been posed to them in order to make detailed explanations. Every interview lasted nearly 20 minutes. When presenting the findings that have been got from the interviews data some abbreviations have been made. Explanations of these abbreviations are as follow:

R: Researcher

TC: Teacher Candidate

$\mathbf{T C}_{\mathbf{1}}$ : First teacher Candidate, $\mathbf{T C}_{\mathbf{2}}$ : Second Teacher Candidate, $\mathbf{T C}_{3}$ : Third Teacher Candidate, $\mathbf{T C}_{\mathbf{4}}$ : Fourth Teacher Candidate.

\section{Data Analysis}

In the process of data analysis the views of the teacher candidates are classified and summarized in the framework of certain themes with a descriptive approach. The main purpose of in content analysis to reach concept that are able to explain the collected data and relations. The first stage of the content analysis is data coding. We try to identify the data and to reveal the realities that may be hidden in the data. The main procedure that is made in content analysis is to gather the similar data in the framework of certain concepts and themes and to interpreted them in a way that reader can understate them (p. 259) [24]. In the data analysis, analysis method is used. Content analysis is identified as a technique by which some words of one text is summarized by smaller content categories. It is systematic and repeatable [31, 32].

In the context of ensuring validity and credibility the interviews that have been made with teacher candidates in this research data has been recorded by permission of the resource persons (candidates) and it is promised that all data would be annihilated subsequent to the study. The data recorded have been listened to the teacher candidates it has been asked if there was and deficiency, if ever, they would be annihilated. After confirmation of Teacher candidates have been taken in the meaning of approval the data that has been obtained in the scope of the research have been analyzed by using content analysis technique. In the context of content analysis data has been classified categorically, and views have been taken by the expert academicians by they have been listened to or watched. By analyzing the data frequency distribution $((f)$ and their percentage $(\%)$, the data and views obtained from the teacher candidates who have participated to the research are placed in the study as a direct citation. After this stage the findings that have been obtained from the analysis are presented largely.

\section{Micro Teaching Application}

It has been found out that the students educating at the Education Faculty Teaching Department had some difficulties in using Turkish correctly, effectively and beautifully that had to have it in direction of applying teaching profession as well as in expression ability, reasoning ability, communication skills, self-confidence and persuasive ability and ability of speaking before audience and using some language skills such as stress, intonation, stopping, diction. This is problem for them to practice teaching. It is well understood that this group that have problems and difficulties make a sampling by having views from the expert academicians accordingly micro teaching application was necessary for them. By paying regard to these suggestions a periodical plan has been prepared in the scope of Turkish First reading and written teaching and by giving subjects related to the lesson. By making preparations in relation to the subjects given (literature scanning, lesson plan related to the subject, preparing convenient and available materials) and by benefiting from the educational Technologies the teacher candidates has given the lessons by micro teaching method for 14 weeks. Every week 3 teacher candidates is given term of one hour and in this way 
applications have been conducted. During the applications each teacher candidate had found the possibility to apply micro teaching application in two times. In the applications for 14 weeks micro teaching has been realized in the scope of special lesson methods. During the representation of lesson the teacher candidates have never been subjected to any intervention. All of the applications have been made in the surveillance of the researcher. Representation of lectures has been recorded by camera and subsequently necessary feedbacks have been taken after the candidates watched them. In the end of each lecture interviews have been made with the candidates one by one and the images have been watched and the views related to the lesson presentation have been determined. During these interviews teacher candidates have been asked to make evaluate. It has been mentioned the deficiencies observed by the researcher and made suggestions. Afterwards interviews have been made with all teacher candidates and lecture presentations have been watched again and teacher candidates have been asked to assess each other.

In order to determine the views of teacher candidates related teaching method a semi-structured interviewing form has been regulated. The purpose of using interviewing form is to be able to analyses the views of the teacher candidates about micro teaching method in depth. The interviewing form that has been regulated has been realized after the application of micro teaching method for 14 weeks.

In the assessment of data obtained by interviewing records, suring conducting interviews has never made any changes in order to support the data. All data obtained from the scope of research have been controlled by the expert views and the research findings have been enriched by the different perspective of views.

\section{Findings}

\subsection{Findings Obtained in the end of Interviews}

The answers of the teacher candidates to the questions in the interview forms intended for the applications executed in the scope of teaching method are analyzed and replaced in the following form in the way of questions-answers:

Question 1: "As being a class teacher candidate have you ever applied micro teaching method in your career? If you do in which scope and how did you apply it?

The answers of the teacher candidates to the Question 1 are as follow:
Table 1. The Situation of Micro Teaching Method Applications Prior to First Reading and Writing Education Lesson.

\begin{tabular}{|c|c|c|c|}
\hline \multirow{2}{*}{ Question of Interview } & \multicolumn{2}{|c|}{ Categories } & \multicolumn{2}{|c|}{$\begin{array}{c}\text { Frequency and } \\
\text { Percentage }\end{array}$} \\
\cline { 2 - 4 } & & $f$ & $\%$ \\
\hline $\begin{array}{c}\text { As being a class teacher } \\
\text { candidate have you ever applied } \\
\text { micro teaching method in your } \\
\text { career? If you do in which scope } \\
\text { and how did you apply it? }\end{array}$ & $\begin{array}{c}\text { No, I have never } \\
\text { applied it. }\end{array}$ & 14 & 70.00 \\
\cline { 2 - 4 } & Yes, I have. & 6 & 30.00 \\
\hline
\end{tabular}

When the answers given by the teacher candidates about micro teaching and application form pertaining to this method are investigated it has been found out that 14 teacher candidates have never been applied it and they had any idea about it prior to the applications made in this lesson. On the other hand, 6 teacher candidates declared that they had knowledge about it and applied it in some lessons. It has been observed from the answers taken from the teacher candidates that they have evaluated the micro teaching as same as subject expositions.

Some answers given categorically are as follow:

$T_{C_{1}}$ : "No, I have never had opportunity to apply micro teaching neither in high school nor in university. Those applications have no values and students are taking into consideration; however, I have got to know micro teaching in this class."

$T_{C_{16}}$ : "No, I have beaver used before; but from what I have heard from my friends It seem to me that it is applied by video and watched repeatedly).

$\boldsymbol{T C}_{8}$ : "Yes, we have practiced at science and lab classes. I have given lectures in the classroom by picking up various subjects related to this lesson. Apart from that there has not been any video shot or anything".

$T_{C_{13}}$ :" No, I have never practiced this method before. I took the opportunity at 3 classes at university to apply this method independently. I felt myself teacher by self-confidence, I realized the active learning."

Even though the teacher candidates know the micro teaching method theoretically, they got into terrible with contradiction in terms as they never practiced this method before or they evaluate the subject lecture as being micro teaching. On the other hand, they have never engaged in activities in the subjects of education method and techniques on practice.

Question 2: "In the context of initial reading and writing education as being a teacher candidate micro teaching method you applied what kind of contributions made up your personal and professional development?

The answers given by the teacher candidates are in the following table: 
Table 2. The Situation of Contribution of Micro Teaching Method Applied İ First Reading And Writing Teaching To The Teacher Candidates.

\begin{tabular}{|c|c|c|c|}
\hline \multirow[t]{2}{*}{ Interview Question } & \multirow[t]{2}{*}{ Categories } & \multicolumn{2}{|c|}{$\begin{array}{c}\text { Frequency } \\
\text { And } \\
\text { Percentage }\end{array}$} \\
\hline & & $f$ & $\%$ \\
\hline "In the context of initial & $\begin{array}{l}\text { It provided a realistic } \\
\text { environment. }\end{array}$ & 2 & 10.00 \\
\hline $\begin{array}{c}\text { reading and writing education } \\
\text { as being a teacher candidate } \\
\text { micro teaching method you } \\
\text { applied what kind of } \\
\text { contributions made up your } \\
\text { personal and professional } \\
\text { development? }\end{array}$ & $\begin{array}{c}\text { It helped substantially in the } \\
\text { subjects of expression skill, } \\
\text { reasoning skill, } \\
\text { self-confidence-making } \\
\text { interpretation skill, using } \\
\text { body language properly, and } \\
\text { suppressing excitement } \\
\text { before audience. }\end{array}$ & 18 & 90.00 \\
\hline
\end{tabular}

When the answers given by the resource persons (teacher candidates) to the 2. Question is examined it has been found out that they are like minded about benefits of the micro teaching. Two persons of the teacher candidates mentioned the importance of learning environment that is created by this method and 18 teacher candidates assess the question in terms of expression skill before audience, body language and activities suppressing excitement.

TC2, TC14, TC17, mentioned about "to suppress board phobia and gain self-confidence. TC13, TCA20 opined as "a realistic environment is brought about". TC1, TC3, TC7, TC2, TC9, TC6, TC12, TC14, TC15, TC17, and TC16 said "I learned to use body language, to express myselffreely before audience, practicing teaching profession and developing speech skill."

Some teacher candidates voiced their views in the frame of the themes above in following way:

$\boldsymbol{T C}_{1}$ :" It developed my using language effectively skill. My self-confidence increased."

$\boldsymbol{T C}_{2}$ : "In the beginning my hands were trembled when I took the floor and I used to be much excited. I did not how I give the lecture and how I make a speech. Thanks to this method I learned that I easily make communication with students and I suppress my excitement."

$\boldsymbol{T C}_{3}$ : "It was a realistic environment. I felt that I behaved as a proper Picture."

$\boldsymbol{T C}_{17}$ : "I gave the lecture by interaction with my friend. I expressed myself freely. I have no fear about taking the floor and being before audience any longer. I have opportunity to express myself."

$\boldsymbol{T C}_{14}$ : "It promoted my speech skill. I have learned how I address the students, how I use mimics and gestures, how I behave as well as to make stresses and intonations in better way."

$\boldsymbol{T C}_{12}$ : "As a teacher candidate I can now express myself more freely".

$\boldsymbol{T C}_{15}$ : "I feel that it is very beneficial for the friends who have difficulty to express themselves. They are now having no difficulty when they make speech before audience".
It has been observed that micro teaching method made a positive impression on the students particularly in terms of expression skill, using body language, submission fear and excitement, effective communication.

Question 3: "What kind of problems did you face in the context of first reading and writing education during the micro teaching applications you executed as a teacher candidate?

The answers of the teacher candidates are in the following table:

Table 3. Difficulties Experienced İn Micro Teaching Method Applied İn First Reading and Writing Lesson.

\begin{tabular}{|c|c|c|c|}
\hline \multirow[t]{2}{*}{ Interview Question } & \multirow[t]{2}{*}{ Categories } & \multicolumn{2}{|c|}{$\begin{array}{c}\text { Frequency } \\
\text { And } \\
\text { Percentage }\end{array}$} \\
\hline & & $f$ & $\%$ \\
\hline \multirow{5}{*}{$\begin{array}{l}\text { "What kind of problems } \\
\text { did you face in the context } \\
\text { of first reading and } \\
\text { writing education during } \\
\text { the micro teaching } \\
\text { applications you executed } \\
\text { as a teacher candidate? }\end{array}$} & I excited and felt apprehension. & 3 & 15.00 \\
\hline & I had time difficulty. & 1 & 5.00 \\
\hline & $\begin{array}{l}\text { I had difficulties in making } \\
\text { speech. }\end{array}$ & 2 & 10.00 \\
\hline & $\begin{array}{l}\text { I experienced lack of } \\
\text { self-confidence. }\end{array}$ & 1 & 5.00 \\
\hline & I have had no problem. & 13 & 65.00 \\
\hline
\end{tabular}

When the answers given by the resource persons (teacher candidates) to the 3. Question is examined it has been found out that 3 teacher candidates felt excitement and apprehension, 2 teacher candidates had difficulty to make speech and 1 candidate felt lack of self-confidence. On the other hand 13 teacher candidates had no any difficulties. When the above answers are examined it is observed that lack of applications cause excitement and apprehension as well as lack of self-confidence and difficulties in making speech. Especially micro teaching applications have important roles in removing such problem sort lower them to minimum level.

The teacher candidates expressed following points in terms of micro teaching method applications which are summarized their perspectives of views:

$\boldsymbol{T C}_{14}$ : "I have had no problems. Applications are more pleasurable. I love this class."

$\boldsymbol{T C}_{\mathbf{2 0}}$ : "I felt lack of self-confidence as it was a realistic environment and I had less experience".

$\boldsymbol{T C}_{13}$ : "Oh, tracking myself after the applications give me excitement and apprehension".

$\boldsymbol{T C}_{15}$ : "In the past we teach passively. We began to be active in this lesson; but as we lack of enough vocabulary we are having difficulty in making speech."

TC9: "I have had no problems. I have already learnt how and when behave. As I am active in lessons I have had no problems in terms of communication".

$T_{C_{8}}$ : "I use my body language better and I constitute communication better. My excitement and apprehension have been pretty reduced."

In the foundation of the difficulties that are experienced 
during the applications of micro teaching method it has been observed express oneself, making verbal communication, self-confidence and excitement and apprehension.

Question 4: "What are your views about micro teaching method applications in the scope of the first reading and writing education?"

The answers of the teacher candidates are in the following table:

Table 4. Perspectives for the Micro Teaching Method Applied In First Reading and Writing Lesson.

\begin{tabular}{|c|c|c|c|}
\hline \multirow[t]{2}{*}{ Interview Question } & \multirow[t]{2}{*}{ Categories } & \multicolumn{2}{|c|}{$\begin{array}{c}\text { Frequency } \\
\text { And } \\
\text { Percentage }\end{array}$} \\
\hline & & $f$ & $\%$ \\
\hline \multirow{5}{*}{$\begin{array}{l}\text { "What are your views } \\
\text { about micro teaching } \\
\text { method applications in } \\
\text { the scope of the first } \\
\text { reading and writing } \\
\text { education?" }\end{array}$} & $\begin{array}{l}\text { I experienced teaching } \\
\text { profession. }\end{array}$ & 8 & 40.00 \\
\hline & $\begin{array}{c}\text { I found possibility to use Turkish } \\
\text { in better way. }\end{array}$ & 6 & 30.00 \\
\hline & $\begin{array}{l}\text { Now we aware of our } \\
\text { deficiencies... }\end{array}$ & 2 & 10.00 \\
\hline & $\begin{array}{l}\text { It contributed to use body } \\
\text { language and expression skill. }\end{array}$ & 2 & 10.00 \\
\hline & $\begin{array}{c}\text { It was helpful for me to make } \\
\text { preparations. }\end{array}$ & 2 & 10.00 \\
\hline
\end{tabular}

When the answers given by the resource persons (teacher candidates) to the 4. Question is examined it has been found out that 8 students stated that they had found opportunity to realize themselves by practicing and experiencing teaching profession. On the other hand, 6 students felt themselves free in using Turkish effectively. 2 students of the teacher candidates it had been helpful for them to see their deficiencies. 2 students of the teacher candidates stated that it contributed to an effective interaction in terms of using body language and communication. 2 students of the teacher candidates said that teaching profession is not simple as it is considered and they learned making preparations beforehand by getting ready some materials.

Teacher candidates expressed their views about micro teaching method in the following way:

$T_{C_{10}}$ : "I have learnt when and how I behave in class as well as my self-confidence increased about stress, intonation, class management."

$\boldsymbol{T C}_{7}$ : "Micro teaching method had been so helpful. Thanks to this method we saw our deficiencies and faults and we tried to shun them. This certainly will make contribution to our profession lives."

$\boldsymbol{T C}_{6}$ : "Micro teaching method has contributed to me in making speech before audience freely by suppressing my excitement and to make address."

$\boldsymbol{T C}_{17}$ : "It gave us probability to realize ourselves at board to feel as if we were real teachers. It had been helpful in terms of suppressing excitement, adjusting intonation, and dominating the class."

$\boldsymbol{T C}_{15:}$ :I have used Turkish effectively and correctly. I suppressed my excitement. Now I am able to adjust intonation and making stress. My verbal communication has been developed."

When the answers given by teacher candidates are examined it is seen that there is no any negative evaluation. In the general meaning, they said that they used Turkish effectively, correctively and beautifully by suppressing excitement, feeling experience of teaching and executing sound verbal communication.

Question 5: "What kind of contribution micro teaching applications made to you in terms of expression ability, reasoning ability, communication skills, self-confidence and persuasion ability, presentation before audience and using Turkish effectively, correctly and beautifully?

The answers of the teacher candidates are in the following table:

Table 5. Expressing And Reasoning Power of Micro Teaching Method Applications as well as İts Effect on Self-Confidence, Persuasion Ability, Representation Before Audience And Correct, Effective And Beautiful Usage Of Turkish.

\begin{tabular}{|c|c|c|c|}
\hline \multirow[t]{2}{*}{ Interview Question } & \multirow[t]{2}{*}{ Categories } & \multicolumn{2}{|c|}{$\begin{array}{c}\text { Frequency } \\
\text { And } \\
\text { Percentage }\end{array}$} \\
\hline & & $f$ & $\%$ \\
\hline \multirow{6}{*}{$\begin{array}{l}\text { "What kind of } \\
\text { contribution micro } \\
\text { teaching applications } \\
\text { made to you in terms of } \\
\text { expression ability, } \\
\text { reasoning ability, } \\
\text { communication skills, } \\
\text { self-confidence and } \\
\text { persuasion ability, } \\
\text { presentation before } \\
\text { audience and using } \\
\text { Turkish effectively, } \\
\text { correctly and } \\
\text { beautifully? }\end{array}$} & Not made... & 2 & 10.00 \\
\hline & $\begin{array}{c}\text { Increased my self-confidence } \\
\text { encouraged me. }\end{array}$ & 3 & 15.00 \\
\hline & $\begin{array}{c}\text { My communication skill } \\
\text { developed. }\end{array}$ & 3 & 15.00 \\
\hline & Contributed to my expression skill. & 3 & 15.00 \\
\hline & $\begin{array}{c}\text { I gained the habit of making speech } \\
\text { before audience. }\end{array}$ & 4 & 20.00 \\
\hline & $\begin{array}{c}\text { It had been helpful for me in terms } \\
\text { of using Turkish effectively and } \\
\text { beautifully. }\end{array}$ & 5 & 25.00 \\
\hline
\end{tabular}

In the 5. Questions it is questioned about language skills of the students during the micro teaching applications. 5 students said that it contributed to their using Turkish effectively and beautifully, 4 students said that it contributed to them in making speech before audience, 3 students said that it contributed to their expressions skills and other 3 students told us that it contributed to their self-confidence and 2 students asserted that it had no effects on them. Questions it is questioned about language skills of the students during the micro teaching applications. 5 students said that it contributed to their using Turkish effectively and beautifully, 4 students said that it contributed to them in making speech before audience, 3 students said that it contributed to their expressions skills and other 3 students told us that it contributed to their self-confidence and 2 students asserted that it had no effects on them.

Teacher candidates expressed the following views in regard with the effects of the micro teaching method on language development:

$\boldsymbol{T C}_{20}$ : "I used to tremble as a leaf before audience; now I feel myself free. Thanks to this method I can express 
myself easily. I think that now I speak Turkish effectively and beautifully. I nearly get the jitters in the beginning." $\boldsymbol{T C}_{1:}$ "It developed my expression skill.

$\boldsymbol{T C}_{19}$ : "This method has made contribution to me in many aspects. I have enriched my oratory skill at the board. Now I speak Turkish effectively and beautifully.

$\boldsymbol{T C}_{4}$ "The most important aspect of this method for me that my self-confidence has been increased substantially.

$\boldsymbol{T C}_{5}$ : "It gave me self-confidence in order to express myself in better way."

$\boldsymbol{T C}_{8:}$ "It provided me with the skills of to make speech before audience effectively, make communication in class, and to grasp the meaning of mimics, to talk in easy way, suppressing excitement, the most important is to use Turkish effectively and beautifully."

$\boldsymbol{R} \boldsymbol{C}_{17:}$ :In the first application I felt my legs were trembling; and in the second application I had gained self-confidence. In the beginning I had no my reasoning power. But afterwards in the second application I raised one level. You are takin the floor in front of the audience and while leaving there you can say "I have done it!" with rejoice. Even you have been applauded by the spectators".

When the answers are examined it is well seen that the teacher candidates give great importance for the micro teaching method especially in addressing to the points such as presentation skill before the audience, making communication effectively, depressing excitement, having self-confidence, using body language effectively, using Turkish effectively and beautifully.

Question 6: "What kind of contribution micro teaching method made to your speech skill in the context of verbal communication, stress, intonation, pause, diction etc. as well as to make speech in various topics and correction of language and phrase errors?"

The answers of the teacher candidates are in the following table:

Table 6. The Situation of Contribution of Micro Teaching Method Applications of the Teacher Candidates on Speaking Skills as Well as in Subjects Such as the Main Features of a Good Speaker, Prepared Making Speech in Various Aspects such as Stress, İntonation, Pause, Diction Etc., Correcting Language and Expression Faults in the Verbal Communication Context.

\begin{tabular}{|c|c|c|c|}
\hline \multirow[t]{2}{*}{ Interview Question } & \multirow[t]{2}{*}{ Categories } & \multicolumn{2}{|c|}{$\begin{array}{c}\text { Frequency } \\
\text { And } \\
\text { Percentage }\end{array}$} \\
\hline & & $f$ & $\%$ \\
\hline \multirow{5}{*}{$\begin{array}{l}\text { "What kind of contribution } \\
\text { micro teaching method made to } \\
\text { your speech skill in the context } \\
\text { of verbal communication, stress, } \\
\text { intonation, pause, diction etc. as } \\
\text { well as to make speech in } \\
\text { various topics and correction of } \\
\text { language and phrase errors?" }\end{array}$} & $\begin{array}{l}\text { My oratory ability } \\
\text { increased. }\end{array}$ & 4 & 20.00 \\
\hline & \begin{tabular}{|c|} 
It contributed to stress and \\
intonation.
\end{tabular} & 5 & 25.00 \\
\hline & $\begin{array}{l}\text { It contributed to my speech } \\
\text { ability. }\end{array}$ & 7 & 35.00 \\
\hline & It effected on my diction. & 4 & 20.00 \\
\hline & $\begin{array}{l}\text { My oratory ability } \\
\text { increased. }\end{array}$ & 4 & 20.00 \\
\hline
\end{tabular}

In the answers given to the Question 6 in the scope of verbal communication 4 students of the teacher candidates expressed that the method contributed to the oratory ability, 5 students aid that it contributed to stress and intonation, 7 students stated that it contributed making speech skill. The answers given by the candidates specified that micro teaching applications contributed substantially to the communication skills of the candidates.

The teacher candidates expressed their views on the effect of the micro teaching method applications on the development of verbal communication in the following way:

TC $_{7}$ : "I would say that it is better than previous applications; I understood this from my verbal communication in the class and feedbacks. I would say that I grasp the topics better than the year before and I can express myself conveniently. I have been in good nick especially for gesture, mimic and diction."

$\boldsymbol{T C}_{1}$ : "By means of the micro teaching method applications I grasped how a speaker must behavior before audience and as an individual how I behave in the classroom, how I talk in the class as well as I comprehended the importance of stress, and intonation. In this way I can express myself and I gained my self-confidence."

$\boldsymbol{T C}_{9:}$ "When I took the floor my voice was trembling and I had no idea how I behave and how I address. And under the stress I did now where I place my hands. I had difficulty ringing sentences together. By means of the micro teaching method applications I began to talk Turkish fluently without accent."

$\boldsymbol{T C}_{4:}$ "I would say that I pay more attention to my speech. I think that I behave sensitively about the points such as stress, intonation, diction etc. I get positive feedbacks from the students."

$\mathbf{T C}_{20}$ : "I have learned to talk Turkish nicely, to control my breathing, to correct faulty words, where I will pause in the talking and to control my mimics, and gestures."

$\boldsymbol{T C}_{17}$ : I get used to make speech before audience correctly without giving way to excitement.

$\mathbf{T C}_{3:}$ "We have learned how to speak in the class. I understand that we have to make speech before students fluently and plainly. We must use a language according to their ages and mind. We have also learned to where we should make stress and intonation."

When the answers given by the teacher candidates investigated it especially contributed to the micro teaching method applications such as stress, intonation, and diction.

Question 7: Will you mention the benefits you will gain during the micro teaching method applications under the scope of first reading and writing education lesson?

The answers of the teacher candidates are in the following table: 
Table 7. Effects of the Experiences in Micro Teaching Method Applications on Teaching Profession.

\begin{tabular}{|c|c|c|c|}
\hline \multirow[t]{2}{*}{ Interview Question } & \multirow[t]{2}{*}{ Categories } & \multicolumn{2}{|c|}{$\begin{array}{c}\text { Frequency } \\
\text { And } \\
\text { Percentage }\end{array}$} \\
\hline & & $f$ & $\%$ \\
\hline \multirow{3}{*}{$\begin{array}{l}\text { Will you mention the } \\
\text { benefits you will gain } \\
\text { during the micro teaching } \\
\text { method applications under } \\
\text { the scope of first reading } \\
\text { and writing education } \\
\text { lesson? }\end{array}$} & $\begin{array}{l}\text { I experienced teaching in the } \\
\text { real. }\end{array}$ & 10 & 50.00 \\
\hline & $\begin{array}{l}\text { I gained self-confidence and } \\
\text { courage... }\end{array}$ & 3 & 15.00 \\
\hline & $\begin{array}{l}\text { It contributed to my talking } \\
\text { skill. }\end{array}$ & 7 & 35.00 \\
\hline
\end{tabular}

In the question 7 it is asked what is the most important contribution of the micro teaching applications to the teacher candidates. When the answers are investigated 10 students expressed that

It is important for teaching experience, 3 students it is important especially in the point of courage and self-confidence and 7 students told us that it is especially for stress intonation, diction. They added that it contributed to the making speech skill.

The teacher candidates expressed their views about the contribution of micro teaching to the candidates in the following way:

$\boldsymbol{T C}_{\mathbf{9}}$ : "It gave me more self-confidence in the class environment."

$\boldsymbol{T C}_{20:}$ "I have become more demanding in order to raise individuals who are rewarding much for society. My self-confidence increased very much in this point. I am much self-confident."

$\boldsymbol{T C}_{13:}$ "I felt that I am really a teacher thanks to these applications. I have experienced that teaching is so beautiful and joyful but to same extent it is a difficult profession too when it is practiced in real meaning."

$\boldsymbol{T C}_{17}$ : "I have really understood what has to be the class flowing in correct and planned way. By using micro teaching method I learned to provide my students more lasting and effective education and learning media including the subjects that is hard to be understood by my students."

$\boldsymbol{T C}_{6:}$ "The micro teaching method contributed to my skills about how I address my students and how to set communication with them".

$\boldsymbol{T C}_{\boldsymbol{8}}$ : "I have grasped the importance the mass to whom I am going to address, strategical approach, making preparations, stress, intonation etc. in making speech as well as ensuring the motivation of my students."

$\boldsymbol{T C}_{14}$ : "I am sure that it will be helpful for being a good speaker. It will provide to use language by paying regard to effective stress, intonation. I learned that it is very important for verbal communication. I also believe that it will be helpful for me to make easy communication with students by ensuring my self-confidence and communication skill."

When the answers procured by the teacher candidates are investigated which are related to the benefits ensured by micro teaching they gave generally answers to the effect that they voiced their experiences with micro teaching method and, as well as, they add that they have gained self-confidence and they felt that their speaking skills have been promoted.

Question 8. What are your suggestions related micro teaching method applications we use in the scope of first reading and writing lesson?

Table 8. Suggestions of the Teacher Candidates about Micro Teaching Method Applications.

\begin{tabular}{|c|c|c|c|}
\hline \multirow{2}{*}{ Interview Question } & Categories & \multicolumn{2}{|c|}{$\begin{array}{c}\text { Frequency } \\
\text { And } \\
\text { Percentage }\end{array}$} \\
\cline { 3 - 4 } & & $\boldsymbol{f}$ & $\%$ \\
\hline \multirow{2}{*}{$\begin{array}{c}\text { In the scope of first reading } \\
\text { and writing lesson what is } \\
\text { your suggestion about micro } \\
\text { teaching applications we } \\
\text { applied? }\end{array}$} & Time is a little limited. & 3 & 15.00 \\
\cline { 2 - 4 } & $\begin{array}{c}\text { It must be more generalized } \\
\text { applications. I have no } \\
\text { suggestions. }\end{array}$ & 11 & 55.00 \\
\hline
\end{tabular}

$\boldsymbol{T C}_{7}$ : "In the micro teaching method applications in the first reading and writing education class I experienced practicing teaching profession and expressing myself in an effective way without boring the students. I suppressed my excitement and freely I made a speech. I have no any suggestion."

$\boldsymbol{T C}_{5:}$ "I would like to make this method widespread and to use it effectively."

$\boldsymbol{T C}_{12:}$ "By means of micro teaching method applications I felt myself as if I am a real teacher. II have had opportunity to find out the errors and to make them corrected. Now I am able to speak freely."

$\boldsymbol{T C}_{1:}$ "I have no any suggestions. I find the application sufficient. I believe that I will have benefits of this method in my Professional life."

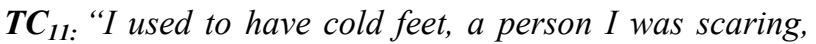
having fear, as well as exciting and therefore shunning to speak. I have gained self-confidence by means of this method. I am more free and easy when I am addressing the class. It contributed to my speaking skills. I have no any suggestions in this point. I think that it will be helpful".

$\boldsymbol{T C}_{9:}$ "Micro teaching method applications made me feel that I am a real teacher. I have realized myself at the board. Now I am able to adjust my excitement and tone of my sound. Now I have an upper hand on the class. For my part the method is sufficient. I have no any suggestions"

$\boldsymbol{T C}_{\mathbf{2 0}}$ : "It is a nice method. My feeling of self-confidence increased. I have no any suggestions."

$\boldsymbol{T C}_{8:}$ "This method must be applied to every student educating at the education faculties. Because by means of this method candidates feel that as if they were a real teacher experienced a real teaching practice." 
$\boldsymbol{T C}_{2:}$ "For my part it would be better time allowed for it must be a little raised."

The teacher candidates give generally positive views about micro teaching method applications. Three students from the teacher candidates opined that time allowed fort his practice should be a little raised and, on the other hand, 11 students felt that the micro teaching method must be generalized. 6 student of the teacher candidates think that the method has no any deficiency, they ate glad to have such method, they experienced a real teacher experience, they realized at the board, their expression of themselves have been developed, they speak easily and freely and their self-confidence increased.

\section{Discussions, Conclusions and Recommendations}

The parallelism between the data obtained by this study and some studies that have been made earlier in relation with the micro teaching method applications is very important. The results of the researches share similarities. It has been revealed by the researches that micro teaching method applications make substantial contribution to the teacher candidates in terms of decreasing the excessive excitement, Professional experience, self-confidence increment, opportunity for the teacher candidates to be able to evaluate themselves, planning in educational system, and other subjects such as class management and communication [33, 34, 35, 36, 37, 38, 39, 40, 41].

Due to the "acquiring self-confidence, decreasing concerns, acquiring teaching Professional information and experiences, presenting lasting learning opportunity, and the opportunity for seeing different application examples and giving opportunity for practical and applied learning environment" the micro teaching applications has been found as pretty effective by the teacher candidates [42]. It is found out that the micro teaching applications are very effective when giving lecture in terms of to make faults, not to know how to correct the faults and errors, not be able to ensure fluency, not to be able to govern the classroom, not to be able to adjust the voice tone, and adjust the speed of speaking, giving lecture before the students, not to be able to attract the attention of the student, forgetting what to say, not to be able to set a demonstration method, not to be able to control the emotions, not to be able to know how finishing the lecture (p.63) [14]. It has been scientifically determined that undeniably the micro teaching applications gives contribution to the individuals in points of verbal communication, analysis-synthesis, solving problems, development in terms of personal and social aspects, to grasp and be grasped.

The micro teaching applications are also effective in noticing the deficiency of speaking and making effort to correct it, to overcome timidity when speaking before audience, using different methods and materials when giving lecture according to the characteristics of the lecture, to be able to govern the class and acquiring self-confidence [43]. When we evaluate the findings in this study that has been conducted for specifying the effect of the micro teaching applications that is realized in the scope of first reading and writing education on the verbal communications skills of the teacher candidates, it has been understood that the teacher candidates evaluate the micro teaching applications positively. The teacher candidate specified that The micro teaching applications makes positive contributions to their abilities in using Turkish according to the rules, correct and beautifully, to Express their emotions and thoughts on a point verbally in effective and clearly, acquiring self-confidence, and acquiring some abilities in using stress, diction, intonation, suppressing excitement as well as to Express themselves clearly and other many subjects. On the other hand, the teacher candidates champion the view that micro teaching applications must be used in every branch effectively. Particularly, in addressing an audience the micro teaching applications make substantial contributions to them especially in some points such as stress and intonation. According to the data gained from the interviews the teacher candidates complained that they are not able to find opportunity to express themselves. They also say that the micro teaching applications are pretty beneficiary in points of expressing themselves verbally, giving lecture by using Turkish correctly and effectively and in this way they learned to manage classes. The teacher candidates are generally glad fort his method, but they also that the time allocated for the applications is not enough.

In the context of results gained by this research it can be giving the following suggestions:

Generalising The micro teaching applications for the all branches at the education faculties in the scope of 2005 Turkish Education Program is very important for the teacher candidates in terms of using Turkish according to their rules fluently, clearly, correct, effective and beautifully, developing in aspects of personal and social, suppressing their excitement, being able to Express themselves, developing the verbal communication skills in the context of speaking skills, increasing their self-confidence.

- It is well seen that classical education method based on academician straight exposition can not satisfy students in terms of professional competency, as well as not be able to remove their deficiencies and cause great gaps particular in verbal communication point. Therefore, in the scope of constructivist learning approach it should be given to the micro teaching applications based on student. It is important the rationale of "lesson can not told but taught" in this point.

- In accordance with teaching programs formed by constructivist learning approach, particularly in Turkish lessons the micro teaching applications can play an important part in learning some points such as suppressing excitements of teacher candidates, gaining self-confidence, breath control, 
representation before an audience, speaking skill, developing expression ability, stress, intonation and diction. For this reason, using this method widely certainly will make contributions to the development of language.

- When it is considered that teaching practicing is made in the last class, particularly the micro teaching applications may be used intensively in using Turkish correctly, effectively and beautifully, acquiring expression ability, reasoning power, communication skills, self-confidence ability, representation before an audience ability, as well as in the main properties of a competent speaker such as stress, intonation, pause and diction, raising readiness level of the teacher candidates.

\section{REFERENCES}

[1] Sever, S. (1998). Dil ve İletişim. Ankara Üniversitesi Eğitim Bilimleri Fakültesi Dergisi, C. 31, ss.51-66.

[2] Ergin, A. (2008). Eğitimde etkili iletişim.(4. bask1) Ankara: An1 Yayınc1lik.

[3] Signe, P. \& Van Schaik C.P. (2000). Dominance and Communication: Conflict Management İn Various Social Setting. Natural Conflict Resolution. (Ed: Aureli F, de Waal FBM). USA: University Of California Press.

[4] Yalçın, K.S. ve Şengül, M. (2007). Dilin iletişim süreci içerisindeki rolü ve işlevleri. Turkish Studies / Türkoloji Arastırmalar1 Volume 2/2. p.749-769.

[5] Bulut, M. (2013). Importance Of Proverbs And Idioms As A Means Of Language And Culture Transfer In Turkish Education And Instruction. Turkish Studies International Periodical For the Languages, Literature and History of Turkish or Turkic Volume 8/13.Ankara

[6] Aksan, D. (1999). Anlambilim. Ankara: Engin Yayınevi.

[7] Banguoğlu, T. (2007). Türkçenin Grameri. 8. baskı, Ankara: TDK Yayınları.

[8] Cüceloğlu, D. (1993). İçimizdeki Çocuk. İstanbul: Remzi Kitapevi.

[9] Öztürk, A. (1997). The Effects of the drama courses on verbal communication skills of teacher candidates. Ankara Üniversitesi Sosyal Bilimler Enstitüsü (Yayımlanmamış Doktora Tezi), Ankara.

[10] Çelenk, S. (1988). Eğitim Yüksekokulu Öğrencilerinin Öğretmenlik Mesleğine İlişkin Tutumları. Selçuk Üniversitesi Sosyal Bilimler Enstitüsü Yayınlanmamış Yüksek Lisans Tezi.Konya.

[11] Arslan-Kilcan, S. (2006). The Levels Of Elementary Mathematics Teachers' conceptual Knowledge Of The Division With Fractions. Yayınlanmamış Yüksek Lisans Tezi, Abant İzzet Baysal Üniversitesi Sosyal Bilimler Enstitüsü.

[12] Sevim, S. (2013). Evaluation of Microteaching Applications through Student Teachers' Views. Dicle Üniversitesi Ziya
Gökalp Eğitim Fakültesi Dergisi, Vol.21 p.303-313.

[13] Ostrosky, Michaelene M.; Mouzourou, Chryso; Danner, Natalie, and Zaghlawan, Hasan Y. (2013). "Improving Teacher Practices Using Microteaching: Planful Video Recording and Constructive Feedback", Young Exceptional Children, 16(1), 16-29. doi: 0.1177/1096250612459186

[14] Görgen, İ. (2003). The Effect Of Microteachıng Practices On Student Teachers' Views Of Giving Lessons In The Classroom. Hacettepe Üniversitesi Eğitim Fakültesi Dergisi $24: 56-63$.

[15] Doğanay, A. (2009). Öğretim ilke ve yöntemleri (4. Bask1). Ankara: Pegem Akademi Yay.

[16] Keser, H. (2007). Öğretim yöntemleri ve yaklaşımları. İçinde Leyla Küçükahmet (Ed.) Program geliştirme ve öğretim (20.Baskı) (s. 108-113). Ankara: Nobel Yayınları.

[17] Şen, A. İ. (2010). Effects of peer Teaching and microteaching on teaching skill of preservice physics teachers. Education and Science, 35 (155), 78-87.

[18] Taşpınar, M. (2007). Kuramdan uygulamaya öğretim ilke ve yöntemleri. Ankara: Nobel Yayınları.

[19] Bulut, K., Açık, F. ve Çiftçi, Ö. (2016). The Effect of Microteaching on Pre-Service Turkish Language Teachers' Speaking Skills. Ana Dili Eğitimi Dergisi, 4(1): 134-150.

[20] Kuş, E. (2003). Nicel-Nitel Araştırma Teknikleri. Ankara: Anı Yayıncilık

[21] Ekiz, D. (2003). Eğitimde Araştırma Yöntem ve Metotlarına Giriş. Ankara: Anı Yayıncılık.

[22] Creswell, J.W. (1998). Qualitative inquiry and research design: Choosing among five traditions. California: Sage Publications.

[23] Tavşancıl, E. ve Aslan, E. (2001). İçerik Analizi ve Uygulama Örnekleri. İstanbul: Epsilon Yayıncılık.

[24] Yıldırım, A.ve Şimşek, H. (2013). Sosyal Bilimlerde Nitel Araştırma Yöntemleri (9.Baskı). Ankara: Seçkin Yayıncılık.

[25] Munn, P., Johnstone, M., \& Holigan, C. (1990). Pupils' perceptions of effective disciplinarians. British Educational Research Journal, 16(2), 191-198.

[26] Miles, B.M. \& Huberman A.M. (1994). Qualitative data analysis: An expanded source book. 2nd Ed. California, USA: Sage Publications.

[27] Punch, F. K. (2005). Sosyal araştırmalara giriş, nitel ve nicel yaklaşımlar.(çev. D. Bayrak, H.B. Arslan, Z. Akyüz), Ankara: Siyasal Kitapevi.

[28] Yin, R.K. (2003). Case Study Research Design and Methods (Third Edition). New Delhi: London.

[29] Çepni, S. (2007). Araştırma ve Proje Çalışmalarına Giriş (Gözden geçirilmiş baskı). Trabzon: Celepler Matbaacılık.

[30] Drever, E.(1995). Using semi-structured interviews in small-scale research. Glasgow: SCRE Publication.

[31] Büyüköztürk, Ş., Kılıç Çakmak, E., Akgün, Ö. A., Karadeniz, Ş. ve Demirel, F. (2013). Bilimsel Araştırma Yöntemleri. Ankara: Pegem Akademi Yayıncılı.

[32] Patton, M. Q. (1987). How To Use Qualitative Methods İn Evaluation. California: Sage Publications. 
[33] Arsal, Z. (2014). The Effect of Microteaching on Prospective Teachers' Classroom Management Attitude and Beliefs. Mersin Üniversitesi Eğitim Fakültesi Dergisi. Mersin Üniversitesi Eğitim Fakültesi Dergisi, Cilt 10, Sayı 3, ss. 137 150

[34] Gurbuz, F. (2015). The Views of Pre-Service Teachers Who Take Special Teaching Course Within the Context of Pedagogical Formation Certificate Program About Micro-Teaching Method and A Physics Lesson Plan. International Journal on New Trends in Education and Their Implications, 6(4), 1-17.

[35] Gurbuz, F. (2016). Physics Education: Effect of Micro-teaching Method Supported by Educational Technologies on Pre-service Science Teachers' Misconceptions on Basic Astronomy Subjects. Journal of Education and Training Studies, 4(2), 27-41.

[36] Kılıç, A. (2010). "Learner-Centered Micro Teaching In Teacher Education", International Journal of Instruction, 1(3), 77-100.

[37] Küçükoğlu, A. Köse,E. Taşgın,A. Yılmaz, B. Y., Karademir,Ş.(2012). The Teacher Candidates' Opinions Regarding the Effect of Micro Teaching Implementation on Teaching Skills. Eğitim Bilimleri Araştırmaları Dergisi, Say1:2 No:2.
[38] Marulcu, İ. ve Dedetürk, A. (2014). Pre-Service Science Teachers' Micro-Teaching Practices: An Action Research. Mustafa Kemal Üniversitesi Sosyal Bilimler Enstitüsü Dergisi. Vol.11 No.25, 353-372.

[39] Mergler, A. G. \& Tangen, D. (2010). Using microteaching to enhance teacher efficacy in pre-service teachers. Teaching Education, 21(2), 199-210.

[40] Peker, M. (2009). Pre-Service Mathematics Teacher Perspectives About The Expanded Microteaching Experıences. Türk Eğitim Bilimleri Dergisi, Vol.7, No.2, 353-376.

[41] Savaş, P. (2012). "Micro-teaching videos in EFL teacher education methodology courses: Tools to enhance English proficiency and teaching skills among trainees", Procedia Social and Behavioral Sciences, 55, $730-738$.

[42] Karadağ, R. ve Akkaya A. (2013). Prospective Teachers' Opinions About Micro-Teaching Applications on Primary Reading and Writing Course. Ahi Evran Üniversitesi Kırşehir Eğitim Fakültesi Dergisi (KEFAD) Vol. 14, No. 2, 39-59

[43] Külahçı, Ş. G.(1994). Mikro Öğretimde Fırat Üniversitesi Teknik Eğitim Fakültesi Deneyimi II. Değerlendirme. Eğitim ve Bilim Dergisi. 